\title{
A synopsis of fern galls in Brazil
}

\author{
Marcelo Guerra Santos $^{I^{*}}$ (D) \& Valéria Cid Maia ${ }^{2}$ (iD \\ ${ }^{1}$ Universidade do Estado do Rio de Janeiro, Departamento de Ciências, Rua Dr. Francisco Portela, 1470, \\ 24435-005, São Gonçalo, RJ, Brasil. \\ ${ }^{2}$ Museu Nacional, Quinta da Boa Vista, Departamento de Entomologia, São Cristóvão, 20940-040, Rio de \\ Janeiro, RJ, Brasil. \\ *Corresponding author: Marcelo Guerra Santos, e-mail: marceloguerrasantos@gmail.com
}

SANTOS, M. G, MAIA, V. C. A synopsis of fern galls in Brazil. Biota Neotropica. 18(3): e20180513. http://dx.doi.org/10.1590/1676-0611-BN-2018-0513

\begin{abstract}
Galls are neo-formed plant structures induced by species-specific interaction between an inducing organism and a host plant. Lycophytes and ferns are two distinct plant lineages historically lumped together as pteridophytes. A number of authors suggest low gall frequency in lycophytes and ferns, compared to angiosperms. This study aimed at compiling an updated overview of fern galls in Brazil, providing information on hosts, gall-inducing organisms and associated fauna. The synopsis was compiled using existent data and by updating scientific names and gathering new information obtained by the authors in fieldwork. To date, galls have been recorded on 16 fern species but none on lycophytes. However, the inducer was identified at species level in only three gall morphotypes from three fern species, with a doubtful inducer for Pteridium sp. Galls are induced by mites (Eriophyidae) and insects of the orders Diptera, Lepidoptera, Thysanoptera, and Hemiptera, Cecidomyiidae (Diptera) being the most frequent galler insect.
\end{abstract}

Keywords: Pteridophytes, lycophytes, galls, Neotropical, Cecidomyiidae.

\section{Sinopse de galhas em samambaias no Brasil}

\begin{abstract}
Resumo: Galhas são estruturas vegetais neoformadas induzidas por interações espécie-específicas entre um organismo indutor e uma planta hospedeira. Licófitas e samambaias são duas linhagens de plantas historicamente classificadas juntas como pteridófitas. Diversos autores sugerem que há uma baixa frequência de galhas em licófitas e samambaias, em comparação com as angiospermas. Este trabalho tem como objetivo fornecer um panorama atualizado sobre as galhas em samambaias no Brasil, disponibilizando informações sobre espécies hospedeiras, galhadores e fauna associada. A sinopse foi realizada compilando-se os dados existentes, atualizando os nomes científicos e agregando informações novas obtidas pelos autores em trabalhos de campo. Até o momento, foram registradas galhas em 16 espécies de samambaias e nenhum registro em licófitas. Contudo, em apenas três morfotipos de galhas, de três espécies de samambaias, o indutor foi identificado a nível de espécie, com um indutor duvidoso para Pteridium sp. As galhas são induzidas por ácaros (Eriophyidae) e insetos das ordens: Diptera, Lepidoptera, Thysanoptera, Hemiptera, sendo Cecidomyiidae (Diptera) o galhador mais frequente.
\end{abstract}

Palavras-chave: Pteridófitas, licófitas, galhas, Neotropical, Cecidomyiidae.

\section{Introduction}

Lycophytes and ferns are two distinct plant lineages historically lumped together under various terms, such as "pteridophytes" or "ferns and allied plants" (Smith et al. 2006, PPG I 2016). Interactions between lycophytes, ferns and arthropods, especially in the Neotropical region, are poorly documented, little known and even neglected.

Galls, characteristic neo-formed plant structures created by hyperplasia and cellular hypertrophy that can occur in different plant organs, are generated by species-specific interactions between an inducing organism and a host plant (Mani, 1964; Isaias et al. 2013). While some authors claim that galls can be induced by bacteria, fungi, nematodes, mites and insects (Mani, 1964), others state that their induction is restricted to nematodes, insects and mites (Raman, 2007). Inducers establish a parasitic relationship and manipulate the metabolism of the host plant (Mani 1964, Raman, 2007).

A number of authors suggest low gall frequency in lycophytes and ferns, compared with angiosperms (Mehltreter et al. 2010). The chapter entitled Zoocecidium, published in 1938 in the Manual of Pteridology, is an important review of lycophyte and fern galls (Docters van Leeuwen 1938). Recently, for the Neotropical region, Hanson \& Gómez-Laurito (2005) recorded 18 species of ferns with galls in Costa Rica.

The aim of this study was to perform an updated overview of fern galls in Brazil, providing information on host species, gall-inducing insects and associated fauna. 


\section{Material and Methods}

The synopsis was compiled using existing data, and by updating scientific names and gathering new information obtained by the authors in fieldwork.

Data concerning lycophyte and fern galls were collected from historic reference studies (Houard 1933), in the catalogue of Cecidomyiidae of the world (Gagné \& Jaschhof 2017); in 55 articles from inventories of insect galls in Brazil published between 1988 and 2017 and studies carried out exclusively with fern galls (Kraus et al. 1993, Martins \& Pimenta 1988, Brown et al. 2004, Maia \& Santos, 2011, 2015, Farias et al. 2018).

Lycophyte and fern nomenclatures were updated using the Flora do Brasil 2020 database and the PPG I classification system (2016).

Complementary data were obtained in fieldwork aimed at collecting fern galls in the Atlantic Forest in the following locations: Itatiaia National Park, Serra dos Órgãos National Park, Maricá Environmental Protection Area, Serra do Barbosão Municipal Nature Park (all in Rio de Janeiro state), Campos do Jordão (São Paulo state) and Tiradentes (Minas Gerais state). A total of 12 collections were carried out between 2011 and 2017. All the gall morphotypes were photographed, collected and taken to the laboratory where part of the sample was dissected, in order to obtain immature gall-inducing insects and determine the inducer taxon. Another part was packed in covered plastic pots, labeled and inspected daily until gall rot occurred, to obtain adult gall-inducing insects. Gall shapes were standardized in accordance with Isaias et al. (2013). All the biological material was deposited in the entomological collection of the National Museum (MNRJ) of the Federal University of Rio de Janeiro (UFRJ) and Herbarium of the Teacher Training Faculty (FFP) of Rio de Janeiro State University (UERJ).

\section{Results and Discussion}

The first records of fern galls in Brazil were made by Houard (1933). This author reported six gall morphotypes in five fern species (Table 1). In none of these the inducer was identified at a specific level, one gall was mite-induced (Eriophyidae) and five by the orders Diptera, Hemiptera and Thysanoptera. In Niphidium crassifolium, Houard (1933) found that the inducer is a Coccidae (Hemiptera); Maia \& Mascarenhas (2017) also recorded globoid gall morphotype on the adaxial side of the leaves of this fern (Figues. 1 E-F). However, other insects, including inquilines (Psocoptera, Sciaridae: Diptera and Corythaica cyathicollis (Costa, 1864) Tingidae: Hemiptera), parasitoids (Platygastridae: Hymenoptera) and an unidentified Diptera larva (likely the galler) were found in recent field studies, which raises doubts about the true identity of the inducer. Some species of Platygastridae (Hymenoptera) parasitize Cecidomyiidae gallers (Johnson et al. 2013). Our group is conducting more detailed analyses in an attempt to clarify this issue.

According to Martins \& Pimenta (1988), Dolichophaonia gallicola (Diptera, Muscidae) is the gall-inducing insect of Pteridium aquilinum (Table 1). However, Monteiro \& Oda (1999) question whether this muscid is the gall inducer. These authors argue that the inducer is an inquiline and not a cecidogenous species, since it exhibits the buccal apparatus of a predator.
Kraus et al. (1993) conducted anatomical studies on stem galls of Microgramma squamulosa induced by a microlepidoptera (Gelechiidae: Lepidoptera). Later, Brown et al. (2004) described it as a new species: Tortrimosaica polypodivora (Tortricidae: Lepidoptera). (Figure 1L).

More recently, Maia \& Santos $(2011,2015)$ recorded two stem gall morphotypes in Microgramma vacciniifolia, one ellipsoid-shaped (fusiform) induced by the microlepidoptera Tortrimosaica polypodivora (Figure 1A), and the other spherical (globoid) and induced by the Cecidomyiidae: Diptera Primadiplosis microgrammae (Figure 1B). Two species of parasitoid wasps (Hymenoptera) were also observed: Torymidae and Tetrastichinae (Eulophidae). In microlepidoptera-induced galls a parasitoid wasp Cheloninae (Braconidae) was also recorded, in addition to an inquiline species of Dasineura sp. (Cecidomyiidae: Diptera). In recent fieldwork, a new gall morphotype was recorded for species of Microgramma squamulosa and $M$. vacciniifolia. It is a conical and lenticular leaf gall respectively, with a white waxy layer at the opening on the abaxial side of the leaf, whose inducer remains undetermined (Figures I-J).

Maia et al. (2008) recorded a leaf gall on Cyathea sp., without identifying its inducer. In field studies conducted in Itatiaia National Park, a globoid leaf gall not yet identified, induced by Cecidomyiidae (Diptera), was found on Cyathea dichromatolepis (Figure 1C). A lenticular leaf gall induced by a new species of Cecidomyiidae was recorded on Cyathea phalerata in the Atlantic Forest of Pernambuco state, Brazil (Farias et al. 2018).

Leaf galls were recorded on Pleopeltis hirsutissima (Figure 1D), Pleopeltis minima, Serpocaulon catharinae and Campyloneurum nitidum (Figures 1G-H). In the first two species, the morphotype is globoid and induced by Cecidomyiidae (Diptera). In the third fern species the gall is conical and in the last lenticular, both with a white waxy layer at the opening on the abaxial side of the leaf. However, we were unable to identify the inducers. Witches' broom galls on leaves of Dicranopteris flexuosa was registered, probably induced by mites.

The leaves are the most frequently attacked organ and the shape of the gall is predominantly globoid. The galls are induced by mites (Eriophyidae) and insects of the orders Diptera, Lepidoptera, Thysanoptera and Hemiptera, Cecidomyiidae (Diptera) being the most frequent gall-inducing insect. In other parts of the world, there are records of fern galls induced by Hymenoptera (Balick et al. 1978, Houard 1908, 1933, Docters van Leeuwen, 1938, Bera et al. 2003) and Coleoptera (Docters van Leeuwen 1938, Bera et al. 2003).

There are no specific inventories for the lycophyte and fern galls of different ecosystems worldwide. The most important data are from Costa Rica, where galls were recorded on only 18 of the 1,120 fern species cataloged, that is a ratio of 0.016 (no. of ferns with galls/no. of ferns species) (Hanson \& Gómez-Laurito 2005). In Brazil, galls have been recorded on 16 of the 1,144 fern species cataloged (Flora do Brasil 2020), a ratio of 0.013 . However, the inducer was identified at species level in only three gall morphotypes from three fern species (Maia \& Santos 2011, 2015). To date, no lycophyte species have been recorded as hosting galls in Brazil and Costa Rica. However, there are records of five Selaginellaceae species from India, New Guinea, Germany and the Malay Peninsula (Alston 1945, Docters van Leeuwen 1938, Mani 1964, Patra et al. 2009). 
Fern galls in Brazil

Table 1. Synopsis of fern galls in Brazil. MG: Minas Gerais state, RJ: Rio de Janeiro state, SP: São Paulo state.

\begin{tabular}{|c|c|c|c|c|c|c|}
\hline Family & Host species & $\begin{array}{c}\text { Organ } \\
\text { with gall }\end{array}$ & $\begin{array}{c}\text { Gall } \\
\text { shape }\end{array}$ & Gall-inducing insect & Location & Reference \\
\hline Blechnaceae & $\begin{array}{l}\text { Salpichlaena volubilis } \\
\text { (Kaulf.) J.Sm. } * 1\end{array}$ & Leaf & Leaf roll & Eriophyidae & Not indicated & Houard (1933) \\
\hline Cyatheaceae & Cyathea phalerata Mart. & Leaf & Lenticular & Cecidomyiidae (Diptera) & Pernambuco state & $\begin{array}{l}\text { Farias et al. } \\
(2018)\end{array}$ \\
\hline Dennstaedtiaceae & Pteridium sp.*2 & $\begin{array}{c}\text { Leaf } \\
\text { (Rachis) }\end{array}$ & Fusiform & $\begin{array}{l}\text { Dolichophaonia gallicola } \\
\text { (Albuquerque, 1958) } \\
\text { (Diptera, Muscidae)*7 }^{*}\end{array}$ & Belo Horizonte, MG & $\begin{array}{l}\text { Martins \& } \\
\text { Pimenta (1988) }\end{array}$ \\
\hline Gleicheniaceae & $\begin{array}{l}\text { Dicranopteris flexuosa } \\
\text { (Schrad.) Underw. }\end{array}$ & Leaf & $\begin{array}{l}\text { "Witches" } \\
\text { broom" }\end{array}$ & Mite? & Tiradentes, MG & This publication \\
\hline Hymenophyllaceae & & Leaf & Globoid & Diptera & Not indicated & Houard (1933) \\
\hline \multirow[t]{12}{*}{ Polypodiaceae } & $\begin{array}{l}\text { Campyloneurum nitidum } \\
\text { (Kaulf.) C. Presl }\end{array}$ & Leaf & Lenticular & Not identified & $\begin{array}{l}\text { Serra dos Órgãos } \\
\text { National Park, RJ }\end{array}$ & This publication \\
\hline & \multirow[t]{3}{*}{$\begin{array}{l}\text { Microgramma squamulosa } \\
\text { (Kaulf.) de la Sota }\end{array}$} & $\begin{array}{c}\text { Stem } \\
\text { (Creeping) }\end{array}$ & Fusiform & $\begin{array}{l}\text { Tortrimosaica polypodivora } \\
\text { Brown \&. Baixeras, } 2004 \\
\text { (Tortricidae, Lepidoptera) }\end{array}$ & São Paulo, SP & $\begin{array}{l}\text { Kraus et al. } \\
(1993) \\
\text { Brown et al. } \\
(2004)\end{array}$ \\
\hline & & & & & Nova Friburgo, RJ & This publication \\
\hline & & Leaf & Conical & (Cecidomyiidae, Diptera) & $\begin{array}{l}\text { Campos do Jordão, SP } \\
\text { Nova Friburgo, RJ }\end{array}$ & This publication \\
\hline & \multirow{3}{*}{$\begin{array}{l}\text { Niphidium crassifolium (L.) } \\
\text { Lellinger } * 5\end{array}$} & \multirow[t]{3}{*}{ Leaf } & \multirow[t]{3}{*}{ Clavate } & Coccidae (Hemiptera) & Not indicated & Houard (1933) \\
\hline & & & & Not identified & Itatiaia National Park, RJ & $\begin{array}{l}\text { Maia \& } \\
\text { Mascarenhas } \\
(2017)\end{array}$ \\
\hline & & & & Not identified (Diptera?) & $\begin{array}{l}\text { Itatiaia National Park, RJ } \\
\text { Serra dos Órgãos } \\
\text { National Park, RJ }\end{array}$ & This publication \\
\hline & $\begin{array}{l}\text { Pleopeltis hirsutissima } \\
\text { (Raddi) de la Sota }\end{array}$ & Leaf & Globoid & Cecidomyiidae, Diptera & Serra dos Órgãos, RJ & This publication \\
\hline & $\begin{array}{l}\text { Pleopeltis minima (Bory) J. } \\
\text { Prado \& R.Y. Hirai }\end{array}$ & Leaf & Globoid & Cecidomyiidae, Diptera & Niterói, RJ & This publication \\
\hline & \multirow[t]{2}{*}{$\begin{array}{l}\text { Serpocaulon catharinae } \\
\text { (Langsd. \& Fich.) A.R. Sm. }\end{array}$} & \multirow[t]{2}{*}{ Leaf } & \multirow[t]{2}{*}{ Conical } & \multirow[t]{2}{*}{ Not identified } & $\begin{array}{l}\text { Serra dos Órgãos } \\
\text { National Park, RJ } \\
\text { Itatiaia National Park, RJ }\end{array}$ & This publication \\
\hline & & & & & Minas Gerais, MG & $\begin{array}{l}\text { Rosy Isaias } \\
\text { (Personal } \\
\text { communication) }\end{array}$ \\
\hline & Serpocaulon sp. *6 & Leaf & Lenticular & Thysanoptera*8 & Not indicated & Houard (1933) \\
\hline
\end{tabular}




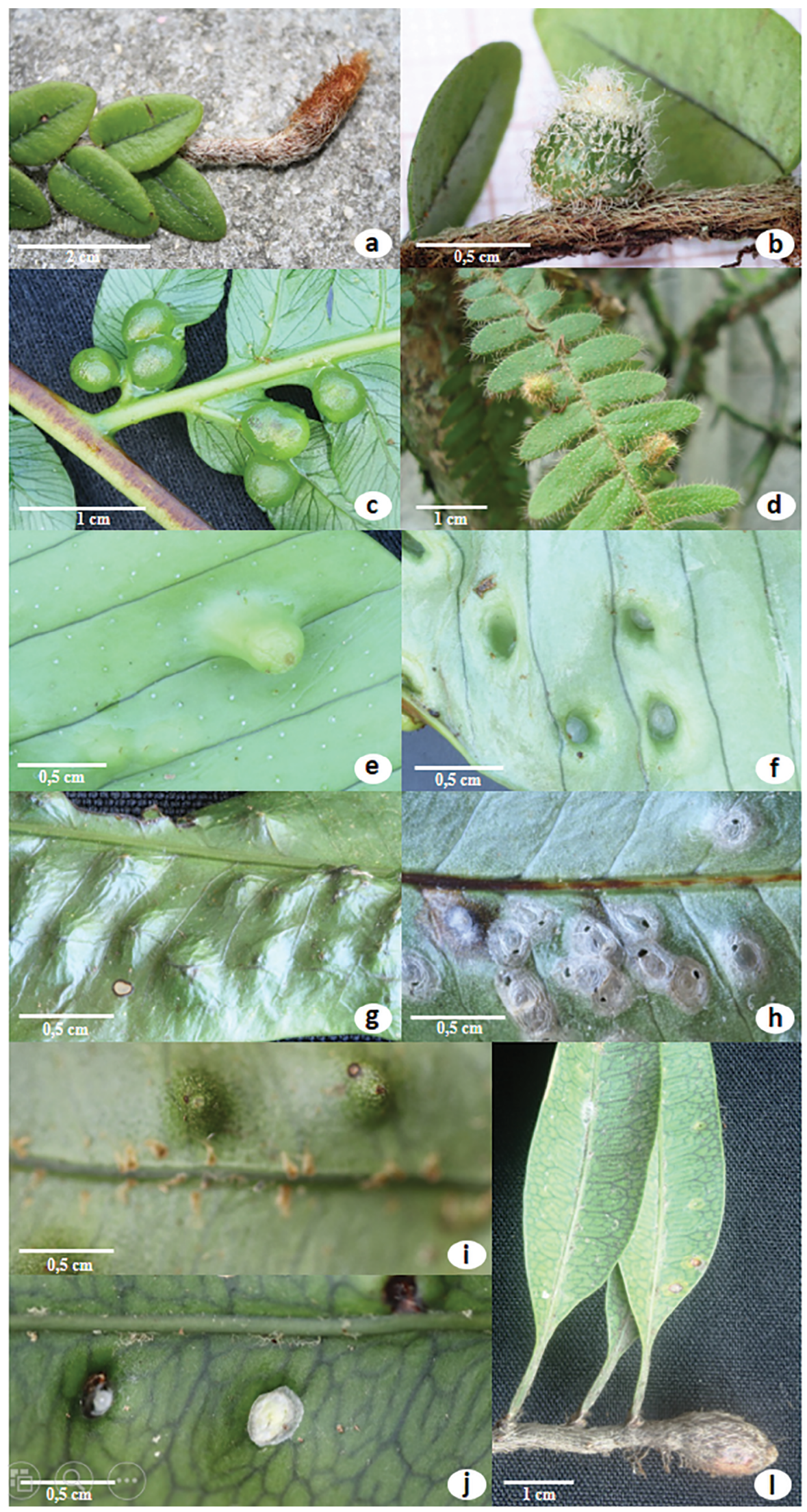

Figure 1. Fern galls in Brazil. a-b Microgramma vacciniifolia. a - Gall induced by Tortrimosaica polypodivora (Lepidoptera). b - Gall induced by Primadiplosis microgrammae (Cecidomyiidae-Diptera). c - Cyathea dichromatolepis. d - Pleopeltis hirsutissima. e-f Niphidium crassifolium, e - adaxial side of the leaf, $\mathrm{f}$ - abaxial side of the leaf. g-h Campyloneurum nitidum. $\mathrm{g}$ - adaxial side of the leaf, $\mathrm{h}$ - abaxial side of the leaf. i-l Microgramma squamulosa. i-j-gall induced by Cecidomyiidae(Diptera). i - adaxial side of the leaf, $\mathrm{j}$ - abaxial side of the leaf. l- gall induced by Tortrimosaica polypodivora (Lepidoptera). All photos by Marcelo Guerra Santos except photo "d" by Alene Ramos Rodrigues. 
The estimated number of ferns worldwide is 10,578 species (PPG I). In line with the methodology used by Espírito-Santo \& Fernandes (2007) and the data collected to date from Brazil and Costa Rica, we estimate an average of 153 fern species with galls worldwide. According to Espírito-Santo \& Fernandes (2007), the Neotropical region is the least studied for galls, despite its substantial plant richness. As such, these values are likely underestimated.

Espírito-Santo \& Fernandes (2007) suggest that for angiosperms there is a positive correlation between gall-inducing insects and plant richness. These authors also underscore the presence of "superhost plants", which may confirm a high richness of gall-inducing insects. In Brazil, the greatest gall richness was recorded for the genus Cyathea, with three species and the family Polypodiaceae, with 10 morphotypes in eight fern species. Three gall morphotypes were recorded in Microgramma vacciniifolia (Table 1).

The present synopsis systematized and broadened the records of fern galls in Brazil, thereby contributing to the knowledge of these interactions worldwide. The biological difficulties in obtaining adult insects precluded identifying their specific level or order. In some cases, the identitity of the galler remains unknown. However, the information presented here is important in designing future studies on the interactions between ferns and insects, especially those involving galls.

\section{Acknowledgements}

The authors would like to thank the CNPq (National Council for Scientific and Technological Development), FAPERJ (Carlos Chagas Filho Research Support Foundation of Rio de Janeiro state) and Scientific, Technical and Artistic Production Incentive Program (PROCIENCIA) of Rio de Janeiro State University (UERJ) for financial support. Thiago Costa for collecting gall samples at Serra dos Órgãos and Rosy Isaias for information about galls on Serpocaulon catharinae. Special thanks to Dr. Nelson Wanderley Perioto and Valmir Antonio Costa for wasp identification and Dr. Luiz Antônio Alves Costa for Tingidae (Hemiptera) identification.

\section{Author's Contribution}

Marcelo Guerra Santos: Substantial contribution in the concept and design of the study; Contribution to data collection; Contribution to data analysis and interpretation; Contribution to manuscript preparation; Contribution to critical revision, adding intellectual content.

Valéria Cid Maia: Contribution to data analysis and interpretation; Contribution to manuscript preparation; Contribution to critical revision, adding intellectual content.

\section{Conflicts of interest}

The authors declare that they have no conflict of interest related to the publication of this manuscript.

\section{References}

ALSTON, A.H.G. 1945. An enumeration of the Indian species of Selaginella. P Indian Acad Sci 11B: 211-235.
BALICK, J., FURTH, D.G. \& COOPER-DRIVER, G. 1978. Biochemical and evolutionary aspects of arthropod predation on ferns. Oecologia 35(1): 55-89.

BERA, S., PATRA, B. \& GHORAI, N. 2003. Animal interaction with pteridophytes with emphasis on Indian records. In Pteridology in The New Millennium (S. Chandra \& M. Srivastava, eds.). Kluwer Academic Publishers, Netherlands, p. 383-395.

BROWN, J.W., BAIXERAS, J., SOLORZANO-FILHO, J. A. \& KRAUS, J.E. 2004. Description and life history of an unusual fern-feeding tortricid moth (Lepidoptera: Tortricidae) from Brazil. Ann Entomol Soc Am 97(5): 865-871.

DOCTERS VAN LEEUWEN, W.M., 1938. Zoocecidia. In Manual of Pteridology (F. Verdoorn, ed.). Martinus Nijhoff, The Hague, The Netherlands, p. 192-195.

ESPÍRITO-SANTO, M.M. \& FERNANDES, G.W. 2007. How Many Species of Gall-Inducing Insects Are There on Earth, and Where Are They? Ann Entomol Soc Am 100(2): 95-99.

FARIAS, R.P., ARRUDA, E.C.P., SANTIAGO, A.CP., ALMEIDA-CORTEZ, J.S., CARVALHO-FERNANDES, S.P., COSTA, L.E.N., BARROS, I.C.L. \& MEHLTRETER, K. 2018. First record of galls in the tree fern Cyathea phalerata (Cyatheaceae) from a Tropical Rainforest in Brazil. Braz J Biol.

FLORA DO BRASIL 2020. http://floradobrasil.jbrj.gov.br/ (last acess in 21 Fev 2017)

GAGNÉ, R.J. \& JASCHHOF, M. 2017. A Catalog of the Cecidomyiidae (Diptera) of the World. 4 ed. Digital.

HANSON, P.E. \& GÓMEZ-LAURITO, J. 2005. Diversity of Gall-inducing Arthropods of Costa Rica. In Biology, Ecology, and Evolution of Gallinducing Arthropods (A. Raman, C.W. Schaefer \& T.M. Withers, eds.). Science Publishers, Inc., New Hampshire. p. 673-692.

HOUARD, C. 1908. Les zoocécidies des plantes d'Europe et du Bassin de la Méditerranée: Description des galles, Illustration, Bibliographie détaillée, Répartition géographique. Librairie scientifique A. Hermann et fils., Paris.

HOUARD, C. 1933. Les Zoocécidies des plantes de l'Amérique sud et de 1'Amérique centrale: description des galles, illustration, bibliographie détaillée, repartition géographique. Hermann, Paris.

ISAIAS, R.M.S., CARNEIRO, R., OLIVEIRA, D.C. \& SANTOS, J.C. 2013. Illustrated and annotated checklist of Brazilian gall morphotypes. Neotrop Entomol 42: 230-239.

JOHNSON, P.J., BUHL, P.N. \& TORREZ, V.C. 2013. A new species of Platygaster Latreille (Hymenoptera: Platygastridae) parasitizing Chilophaga virgati Gagné (Diptera: Cecidomyiidae). Zootaxa 3630 (1): 184-190.

KRAUS, J.E., MONTENEGRO, G. \& KIM, A.J. 1993. Morphological studies on entomogenous stem galls of Microgramma squamulosa (Kauf.) Sota (Polypodiaceae). Am Fern J 83: 120-128.

MAIA, V.C., MAGENTA, M.A.G. \& MARTINS, S.E. 2008. Ocorrência e caracterização de galhas de insetos em áreas de restinga de Bertioga (São Paulo, Brasil). Biota Neotrop 8(1): 167-197.

MAIA, V.C. \& MASCARENHAS, B. 2017. Insect Galls of the Parque Nacional do Itatiaia (Southeast Region, Brazil). An Acad Bras Cienc 89(1 Suppl.): 505-575.

MAIA, V.C. \& SANTOS, M.G. 2011. A new genus and species of gall midge (Diptera, Cecidomyiidae) associated with Microgramma vacciniifolia (Langsd. \& Fisch.) Copel. (Polypodiaceae) from Brazil. Rev Bras Entomol 55(1): 40-44.

MAIA, V.C. \& SANTOS, M.G. 2015. Record of insects in two fern species of the genus Microgramma (Polypodiaceae) in the Atlantic Rain Forest, Rio de Janeiro state, Brazil. Brazil. Braz J Biol 75 253-254.

MANI, M.S. 1964. Ecology of plant galls. Springer-Science.

MARTINS, R.P. \& PIMENTA, H.R. 1988. Phaonia gallicola Albuquerque, 1958 (Diptera:Muscidae) a gall maker on Pteridium aquilinum Kunh. (Pteridophyta). An Soc Entomol Bras 17: 181-182. 
MEHLTRETER, K. 2010. Interactions of ferns with fungi and animals. In Fern Ecology (K. Mehltreter, LR. Walker \& J.M. Sharpe, eds.). Cambridge University Press. p. 220-254.

MONTEIRO, R.F. \& ODA, R.A.M. 1999. Dolichophaonia gallicola (Albuq.) (Diptera: Muscidae): Espécie Cecidógena ou Inquilina? An Soc Entomol Bras 28(3): 531-534.

PATRA, B., BERA, S. \& MEHLTRETER, K. 2009. Structure, biochemistry and ecology of entomogenous galls in Selaginella Pal.Beauv.(Selaginellaceae) from India. J Plant Interact 1-8.
PPG I. 2016. A community-derived classification for extant lycophytes and ferns. The Pteridophyte Phylogeny Group. J Syst Evol 54 (6): 563-603.

RAMAN, A. 2007. Insect-induced plant galls of India: unresolved questions. Curr Sci India 92: 748-757.

SMITH, A.R., PRYER, K.M., SCHUETTPELZ, E., KORALL, P., SCHNEIDER, H. \& WOLF, P.G. 2006. A classsification for extant ferns. Taxon 55 (3): 705-731.

Received: $12 / 01 / 2018$

Revised: $18 / 05 / 2018$

Accepted: 02/06/2018

Published online: 28/06/2018 